\title{
The Dual Role of Senescence in Tumorigenesis
}

\author{
Papel Dual de la Senescencia en la Tumorigénesis
}

Lilian Chuaire-Noack; Magda Carolina Sánchez-Corredor \& Sandra Rocío Ramírez-Clavijo

CHUAIRE-NOACK, L.; SÁNCHEZ-CORREDOR, M. C. \& RAMÍREZ-CLAVIJO, S. The dual role of senescence in tumorigenesis. Int. J. Morphol., 28(1):37-50, 2010.

SUMMARY: Senescence was rendered a tumor suppressor mechanism based on the observation of its protective effect against cancer in young organisms under conditions of oncogene activation or inactivation of tumor suppressor genes. In addition to this beneficial effect, senescence has been deemed to have age-associated deleterious effects because, apparently, senescence not only recapitulates aging and therefore loss of function and tissue regeneration capacity, but can also induce preneoplastic changes in adjacent stromal cells, provoke degenerative diseases or induce the production of tumor cell growth promoting factors. For that reason, senescence has become an attractive therapeutic target against cancer. This paper reviews some of the latest findings on the role of senescence in the malignant progression and analyzes them in relation to the concept of antagonistic pleiotropism, as well as its possible use as a therapeutic target against cancer.

KEY WORDS: Senescence; Cancer; Antagonistic pleiotropism.

\section{INTRODUCTION}

Senescence was first described over 40 years ago by Hayflick and Moorhead as an irreversible state of arrest of the cellular cycle of normal cultured diploid cells which had drained their proliferation capacity (Hayflick \& Moorhead 1961). In such state, known as "replicative senescence", on account of their difficulty to reach in vitro confluence cells acquire a large and flattened morphology reminiscent of mesenchymal cells. Besides becoming multinucleated and highly granular - due to an increase in the number of lysosomes -, senescent cells become resistant to apoptosis (Campisi \& D'Adda di Fagagna 2007). Although research on the field of senescence began with Hayflick and Moorhead, it gained new momentum when Dimri et al. (1995) discovered that the expression of the b-galactosidase enzyme had risen within senescent cells (Dimri et al., 1995). In addition to the senescence-associated B-galactosidase (SA$\beta$-gal), there are currently numerous biomarkers which enable the identification of cells in senescent state, some of which are reviewed below (Table I).

Senescent cells exhibit a peculiar pattern of metabolic activity and of protein-processing shifts. These facts allow to infer that senescent cells modify their normal genetic profile, which includes changes in the expression of genes such as p53, p16, p21, Rb, ATM/ATR and ChK1/ChK2 (Krtolica \& Campisi, 2002; Campisi, 2004; Okada \& Mak 2004; Ben-Porath \& Weinberg, 2005; Schwarze et al., 2005) and in other genes codified by the mitochondrial DNA, such as ribosomal RNA $16 \mathrm{~S}$ and subunit-I gene of NADH dehydrogenase (Katakura, 2006), whose expression increases during senescence. Genes like SIRT1, a sirtuin belonging to the class III histone deacetylase family, are repressed and thereby enzyme activity of the codified protein is absent in senescent cells. This fact favors the permanence of cells in such state and, simultaneously, the generation of an apoptosis-inhibiting effect (Liu et al., 2009).

Resistance to apoptosis explains the heaps of senescent cells in tissue. Because of their capacity to produce substances which alter tissue environment, these heaps may contribute, not only to the aging process, but also to the genesis of diseases such as atherosclerosis, osteoarthritis, muscular degeneration, ulcer formation, coronary disease, Alzheimer, diabetes, endothelial dysfunction, immune exhaustion and cancer (Carnero, 2007), among others.

Another type of senescence known as premature senescence, whether accelerated or induced by stress, may 
Table I. Some senescence biomarkers frequently used nowadays. Their determination may be carried out in vitro, in situ or with tissue biopsies. Amongst them, SA-ß-gal is the most widely employed, in virtue of the simplicity of the procedure, which allows establishing its presence as well as its activity.

Of lysosomic origin, it activates at $\mathrm{pH}$ 6.0. Its expression increase s not only in senescent cells, but

SA-_-gal

also in normal in vitro cells due to the inherent stress of cell culture, serum deprivation, or confluence. It $\mathrm{m}$ ay be detected by means of histochemical methods, with a chromogenic or fluorescent susbstrate (Dimri et al., 1995; Lee et al 2006).

Constituted by facultative heterochromatin, they contain histone proteins such as $\mathrm{H} 3$ Lys9 methylated (H3K9me) and the macroH2A variant of histone H2A (Zhang et al., 2005). Also present

Senesc ence-associated

heterochromatic foci

(SAHFs) are heterochromatin proteins HP1a, b a nd g, as well as HMGA (High Mobility Group A) n onhistones (Narita et al., 2003).

SAHFs contain growth-promoting genes in silent state such as $E 2 F$ target genes (Narita et al., 2003), in a process led by chromatin regulator chaperons HIRA and ASF1a (Zhang et al., 2005). Their presence is thus related to the characteristic irreversibility of the senescent state (Jeyapalan et al., 2007; Narita, 2007).

These foc $\mathrm{i}$ appear as the result of critical telomere shortening and/or other forms of DNA damage.

Senesc ence-associated

DNA-damage response foci (SDFs)

Gene expression patterns

$p 15^{I n k 4 b}, D E C 1$ ( differentiated embryo-chondrocyte transcription factor) and DCR2 (death cell receptor 2) genes are simultaneously overexpressed in senescence, which can be proven with the use of microarrays. (Collado \& Serrano 2006; Campisi \& D’Adda di Fagagna, 2007)

By means of inhibiting Cdks 4 and 6, p16 ink4a indirectly prevents the phosphorylation of Rb (mutated gene in the retinoblastoma). This keeps Rb bound to E2F and hence it induces G1 cell cycle arrest. $p 16^{\text {ink } 4 a}$ expression is higher among cells in replicative senescent state and during aging, as well as in p $16^{\text {ink } 4 a}$

Thanks to the genotoxic signal transduction pathway that activates ATM protein kinase (mutated gene in ataxia-telangiectasia), ATR (mutated gene in ataxia-telangiectasia, related to Rad3), ChK1 (checkpoint-1), ChK-2 (checkpoint-2), the chromatin H2Ax modifier histone is phosphorylated and damage response proteins such as 53BP1, BRCA1, MCD1 and MREIIRad50NBSI may be recruited (Takai et al., 2003). certain tumours which had lost $R b$ (Krishnamurty et al., 2004; Sharpless, 2004; Song et al., 2008; Gil \& Peters, 2006), due to the action of transcription factors such as Sp1, E47, Id1, Jun B y Bmi-1, among others (Wu et al., 2007; Zheng et al., 2004; Pas segue \& Wagner, 2000; Itahana et al., 2003)

well share the majority of morphological and biochemical characteristics with replicative senescence, but unlike the latter, it is produced in an earlier form. Additionally, premature senescence does not involve the participation of the cyclin-dependant kinase inhibitor gene $p 16$-which is in a silent state, especially in cancer cell lines where DNA 
damage induces the senescent state (Gerwitz et al., 2008)-, nor is it related to telomere shortening. Factors such as the activation of certain oncogenes (Mason et al., 2004; Yaswen \& Campisi, 2007; Kilbey et al., 2008), the inactivation of tumor suppressors, chemotherapy, UV and gamma radiations, telomeric dysfunction (Cosme-Blanco et al., 2007; Feldser \& Greider, 2007), TGF- b (Katakura et al., 1999) and $\mathrm{H}_{2} \mathrm{O}_{2}$ (Duan et al., 2005; Lu \& Finkel, 2008) are capable of inducing accelerated senescence in normal and cancerous cells.

Senescence associated secretory phenotype (SASP). Evidence shows that senescence does not correspond to an exclusive phenomenon of cultured cells: it has also been observed in a great variety of normal cells in tissue biopsies. Though resistant to mitogenic stimuli and incapable of dividing, senescent cells stay metabolically active so that, in response to stressful situations, they are capable of activating genes related to the acquisition of a specific phenotype. This phenotype is not only characterized by changes in cell morphology, but also by the production of substances that act inside that very cell and in its surroundings. The characteristic secretory phenotype of senescent cells includes substances such as proinflammatory cytokines, proteases and/or extracellular matrix components, as well as growth factors (Salvioli et al., 2006; Libby, 2006; Bavik et al., 2006; Coppé et al., 2006), which, once they act on nearby cells, might contribute to the process of aging or to the possible genesis or progression of diseases (Jeyapalan et al.). In relation to this matter, it has been proven in vivo and in vitro, that the agents that cause DNA damage induce, in normal and tumor cells, the appearance of genetic expression profiles, some very similar to mitogenic activity, others to antiapoptotic activity and some to angiogenic activity (Coppé et al., 2008; Pascal et al., 2005; Mason et al.; Kletsas et al., 2004; West et al., 1989).

In order to identify the senescent secretory phenotype, Coppé et al. (2008) used normal and tumorigenic cell lines under different dosages of anticancer agents which cause DNA damage. By means of microarrays with antibodies, they were able to identify the secreted factors in presenescent and senescent states. The characterization of the SASP phenotype in treated fibroblasts showed that, in comparison to presenescent cells, senescent cells expressed cytokines IL-6, IL-7, IL-8, MCP-2, MIP-3, chemokine Gro-1 chemoattractant of inflammatory cells, growth factors $\mathrm{HGF}$ and IGFBPs and modulator molecules of immune response such as ICAMs, UPAR and TNF receptors, among others. They also observed that in cells which had lost the p53 function or with a Ras overexpression, the SASP phenotype was accentuated thanks to a quantitative increase in the expression of some of the identified molecules. The microenvironment -autocrine and paracrine- generated by these factors induced changes in the activity of nearby cells, as was confirmed by Coppé et al. (2008), who proved that a conditioned medium obtained from cultured senescent fibroblasts is capable of inducing the proliferation of cultured premalignant and malignant epithelial cells, as well as the tumorigenicity of senescent epithelial cells transplanted to mice. These facts could partly explain the reduction of effectiveness in anticancer therapies whose goal is to cause DNA damage. On the other hand, they could also originate the appearance of secondary cancers from cells with mutations caused by the action of the same agents and that had escaped cell death or senescence.

Although it is not exactly known what determines the appearance of this particular phenotype, according to Burton (2009), it might aim not only to attract and allow the migration of immune cells capable of eliminating senescent cells, but also to induce an ulterior proliferation of nearby cells, so that tissue can be repaired after the removal of the senescent cells (Burton). This mechanism would be effective in young individuals but not in elder ones due to the gradual decline of its efficiency and to the simultaneous aging of the immune cells: these would no longer be able to remove senescent cells. As a consequence, the accumulation of senescent cells alters the functionality of the tissue which shelters them (Burton).

Signaling pathways. The signaling pathways implied in the occurrence of the senescent state are, apparently, the same for both types of senescence -replicative and accelerated-at least in light of DNA damage. Thus, protein kinases ATM and ATR are directly, or by means of the activation of DNA damage sensor kinases ChK1 and ChK2, in charge of enabling the phosphorylation and subsequent stabilization of p53 with the consequent activation of $\mathrm{p}^{21 \text { waf } 1 / \text { cip } 1}$ and the inhibition of cyclin-dependent kinases (Cdks). At the same time, the inactivation of the Cdks leads to the dephosphorylation of $\mathrm{Rb}$, a protein which regains its capacity to form protein complexes with members of the E2F family transcription factors in order to prevent the activation of the E2F target genes and stop the cell cycle (Ben-Porath \& Weinberg; Gerwitz et al.) (Fig. 1). Besides p21waf1/cip1, other effectors of p53 such as 14-3-3 and GADD45 -which act as transition G2/M inhibitors-, are involved in the signaling associated to senescence (Carnero). In the context of replicative senescence, the stabilization of p53 has also been described in terms of $\mathrm{p} 19^{\mathrm{ARF}}$, a tumor suppressor protein that, when bound to Mdm2, promotes p53 degradation through ubiquitination (Lowe et al., 2004; Zhang et al., 1998). Another factor that activates p53 during replicative senescence is the tumor suppressor PML described in promyelocytic leukemia. PML acts as a regulator of $\mathrm{p} 53$ 
acetylation (Roninson, 2003). p53 and p21 expression in senescent cells is transitory, for it decreases once cellular proliferation stops, as opposed to what happens with $\mathrm{p} 16^{\text {ink4a }}$ -another Cdks inhibitor- whose expression increases and is apparently responsible to maintain the growth arrest state in replicative senescence (Roninson).

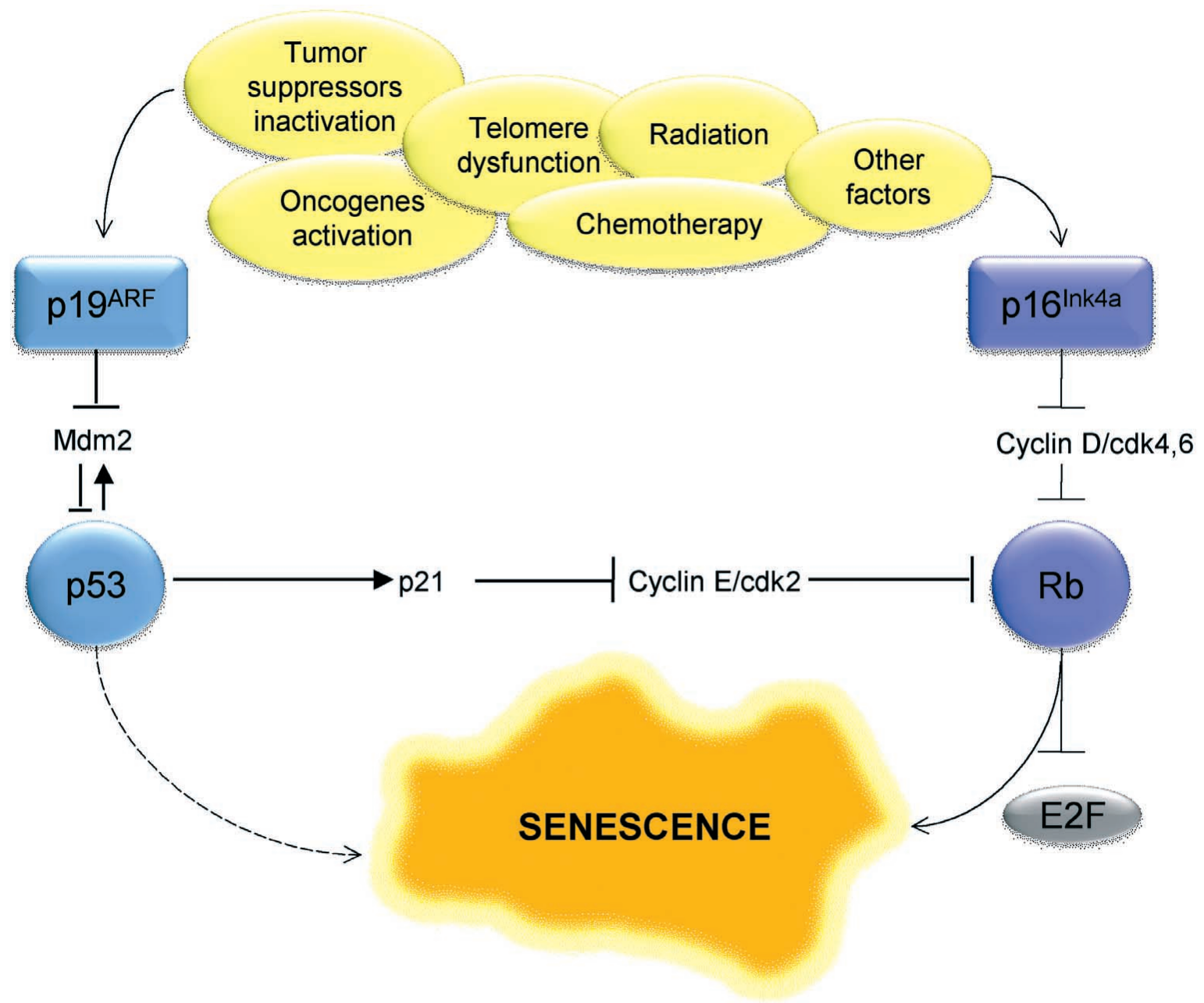

Fig. 1. Senescence activation models. Rb can be lineally activated through p53-p21 pathway, through p16-Rb, or through both pathways at the same time according to specific combinations and/or the severity of the factors that cause stress (BenPorath \& Weinberg, 2005).

Senescence and aging. Aging is the process related to the gradual decrease in the capacity to repair and regenerate tissues in complex organisms. This capacity depends on the proliferation potential of stem or progenitor cells (Beausejour \& Campisi, 2006). This fact has been proven by using the tumor suppressor gene $\mathrm{p} 16$, whose expression increases with age and whose effects are associated to a smaller progenitor cell self-renovation capacity and to the aging of tissues such as the bone marrow, brain and pancreatic islets (Janzen et al., 2006; Krishnamurty et al., 2006; Molofsky et al., 2006).
As the natural aging process advances, senescent cells accumulate and generate a biological impact in the mitotic tissue to which they belong and in adjacent non-mitotic tissues. As a result, tissue function deteriorates gradually, which contributes both to the appearance of the typical aging phenotype in the individual (Kirkwood \& Austad, 2000; Campisi, 2004 ) and to the possible development of late cancers and degenerative diseases such as osteoarthritis and arteriosclerosis (Coppé et al., 2008) (Fig. 2). Additionally, it has been reported that the proliferative and functional de- 
cline in tissues due to the accumulation of senescent cells is the most frequent cause of failure in late organ transplants, in absence of previous episodes of rejection (Song et al.).

Senescence and oncogenesis. The characteristic proliferation signals of oncogenesis are coupled to inhibitory processes of growth such as senescence and apoptosis, for which there is evidence of their function as guardians against neoplastic development (Collado et al., 2005; Michaloglou et al., 2005). In contrast to apoptotic cells, senescent cells are viable, even for a long time, despite their incapacity to proliferate. $p 53$ is the key in both processes, although there are still many question marks concerning the mechanisms that affect a cell's deciding one direction over another in order to avoid tumor transformation.
Notwithstanding the immortality of cancer cells, it has been possible to activate the program of senescence in tumor cell lines through fusion with normal senescent cells. This has allowed identifying various groups of genes related to the senescent state, besides the ones already described, such as $p 63$ and $p 73$-members of the $p 53$ family- other Cdks inhibitors such as $p 27, p 57^{\text {kip } 2}$ and $p 15$, as well as various members of the family of growth factor/ IGF-binding proteins (Jung et al., 2001; Tsugu et al., 2000; Fuxe et al., 2000; Sprenger et al., 2002).

On the role of senescence in in vivo tumor transformation there exists evidence that relates it both to the suppression and stimulation of such process (Fig. 2).

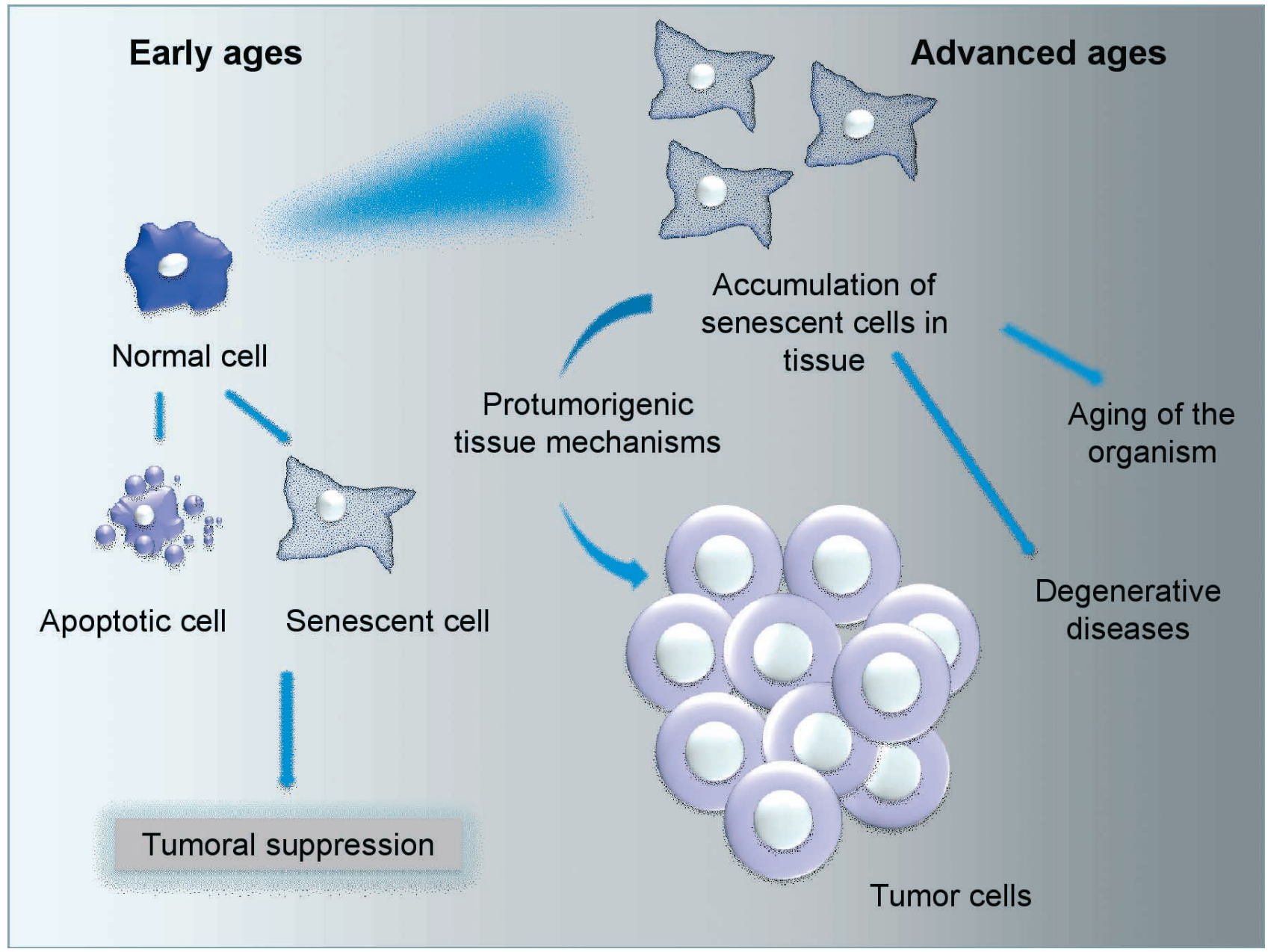

Fig. 2. The dual role of senescence in oncogenesis. In young individuals, senescent cells act as a security mechanism that prevents tumor transformation. In elder individuals, however, the accumulation of senescent cells not only promotes the appearance of a senescent phenotype, but also the generation of a tissue environment which favors tumorigenesis and the appearance of degenerative diseases.

Senescence as a tumor suppressor mechanism. In certain benign dysplastic or preneoplastic lesions and with benign hyperplasia (Braig et al., 2005, Chen et al., 2005), as well as in normal and tumor tissue that underwent chemotherapy (Schmitt et al., 2002; Te Poele et al., 2002; Roninson; Roberson et al., 2005) there have been found accumulations 
of senescent cells with their proper morphological characteristics and lacking invasive capacity. In contrast, when the lesion has progressed towards malignancy, no senescent cells appear. This allows supposing that it is necessary to breach the point of control of senescence for tumor transformation to occur (Pazolli \& Stewart 2008). This begs the question about the manner in which the cells present in premalignant lesions progress towards malignancy: Are the very senescent cells in the lesion the ones that escape from senescence and enter the new cell cycle to proliferate without control and originate a neoplastic lesion? Or, do cells within the premalignant lesion transform directly into malignancy by means of avoiding the senescent state? Although this query has not found solution yet, there exists evidence that such state can be induced both through the activation of oncogenes, and through the inactivation of tumor suppressor genes (Serrano et al., 1997; Lin et al., 1998; Michaloglou et al.; Chen et al.; Braig et al.).

Senescence induced by oncogenes. Under the activation conditions of mitogenic oncogenes the security mechanisms of the cell cycle's checkpoints start functioning. Thus, the revision of the integrity of the DNA and of the necessary elements for the cycle to continue or to stop -when the activation of the DNA repairing machinery is required- as well as the stimulation of apoptosis or senescence are mechanisms that, ideally, allow the solution of a premalignant condition before tumor transformation takes place (Campisi, 2001; Schmitt, 2003). For this reason, the presence of mutations that lead to the activation of oncogenes might facilitate the evasion of such security mechanisms. From avoiding these mechanisms to the beginning of tumor transformation there is only one step, if one bears in mind that mutated oncogenes are additionally capable of intensifying growth-promoting signals, of inhibiting antiproliferative signals, and of altering the proapoptotic signaling.

In this context, it is worthwhile to revise some evidence on the inductor role of senescence performed by some oncogenes such as Ras, Braf ${ }^{\mathrm{V} 600 \mathrm{E}}$ or Prak:

- Ras- Although since 1997 Serrano et al had managed to demonstrate the effect of oncogenic Ras in the induction of premature senescence as well as the effect on the accumulation of $p 53$ and $p 16^{\text {inkta }}$ and the activation of $\mathrm{Rb}$ (Serrano et al.), it was not until 2005 when, thanks to the work of Collado et al., that the protective role that Rasinduced senescence performs against neoplastic development was discovered. Collado et al. induced the appearance of both benign (adenomas) and malignant (adenocarcinomas) pulmonary lesions in mice through the activation of a conditional oncogenic allele KrasV12. As opposed to the cells in the adenocarcinomas, were no senescence markers were found, the cells in the pulmonary adenomas revealed the presence of markers characteristic of the senescent state such as $\mathrm{p} 16^{\text {ink4a }}, \mathrm{p} 15^{\text {ink4b }}$, transcription factor DEC1 (deleted in oesophageal cancer 1) (Qian et al., 2008), DCR2, as well as SA- $\beta-$ Gal and SAHFs. Similar results were obtained from the pancreas and skin papilloma under the induction of senescent state by means of oncogenic Ras, which lead them to propose that in premalignant lesions there exists an important number of cells which suffer senescence induced by oncogenes, in order to restrict malignant transformation. In contrast, such conduct is not possible for cells present in malignant lesions because these have suffered the loss of senescence effectors induced by oncogenes such as $p 16^{\text {ink4a }}$ y p53 (Collado et al.).

- Braf ${ }^{V 600 E}$. This is the case of the dysplastic nevus, a lesion that might be precursor of a melanoma and a lesion in which, although oncogenic mutations characteristic of a melanoma appear, no cell proliferation takes place and, on the contrary, a senescent phenotype characterized by SA-B-Gal expression and the presence of SAHFs is expressed. It is frequent to find mutations in $\mathrm{Braf}^{\mathrm{V}}{ }^{600 \mathrm{E}}$ (gene that codifies for an effector protein kinase of Ras) in this type of lesion. It is nonetheless not possible to find senescent cells within the lesion in case a progression towards malignancy ocurrs (Michaloglou et al.; Ramsey \& Sharpless, 2006).

- Prak. Sun et al. proved in 2007 that Prak -a protein kinase regulated by $\mathrm{p} 38$ and a downstream substrate in the MAPK signaling cascade - is essential in the promotion of the senescent state in response to activation of the Ras oncogen and therefore acts as a defense mechanism against tumorigenesis (Sun et al.). Through the employment of a skin cancer model in mice, they proved that, in activation conditions of Ras, Prak deficiency provoked, parallelly to senescence induction, an increase in the skin's carcinogenesis induced by the dimethyl benzanthracene mutagenic agent (DMBA) and for this reason they suggested that Prakmediated senescence acts in vivo as a barrier against tumor transformation. In addition to this, as they examined primary Prak $^{-1-}$ embrionary fibroblasts, they found that Prak deletion suppressed Ras-induced senescence while at the same time promoting tumoral transformation. The findings of a poor suppression of cell proliferation in Prak overexpression conditions indicate that, opposed to other components in the $M A P K$ signaling pathway, overexpression or oncogenic activation of Prak are not enough to induce senescence (Courtois-Cox et al., 2006), but that the previous activation of Ras is necessary to achieve efficiency as an antitumorigenic mechanism.

It is worth mentioning that Sun et al. not only proved that Prak is indispensable for tumoral suppression during 
Ras-induced tumorigenesis, but also that it acts as a kinase of p53 in serine 37 , a phosphorylation that apparently is key for the beginning of the senescent state. Serine 37 may also be phosphorylated by other kinases other than Prak, in a process involved in the reparation pathways of DNA and of senescence (Sun et al.).

As for the mechanism employed to induce senescence, there is evidence on the role played by oncogenes on an unbalanced replication of DNA and therefore of a classical activation response of the DNA damage checkpoint (Bartkova et al., 2006; Mallette et al., 2007). Thus, Bartkova et al. proved in an interesting manner that the senescence observed in preneoplastic colon lesions was induced by the DNA damage checkpoint in response to stress in DNA replication. In premalignant colon lesions, urinary bladder and cutaneous papillomas of mice was found a strong association between an increased expression of senescence markers induced by oncogenes -such as SA-B-Gal and heterochromatic proteinsand the activation of the DNA damage checkpoint. These results contrasted with those found in the neoplastic lesions examined, where there was an accentuated decrease in such expression, probably due to mutations in genes, such as p53, that take part in the damage checkpoints.

It is feasibly that senescence induced by oncogenes is related to an increased expression of positive regulators from phase $S$, event which favors the premature reactivation or termination of the replicons in the cell cycle and, therefore, favors the appearance of DNA break points. As a consequence, a characteristic response to DNA damage would be produced, which includes, on the one hand, the phosphorylation of p53 and, on the other, the activation of pathway $M A P K$. As a result of $M A P K$ activation, p53 would stabilize due to an increase in $A R F$ expression and the subsequent $M d m 2$ inhibition (Courtois-Cox et al.).

In this context $\mathrm{p} 53$ emerges as an integrating element and effector of DNA damage signals, for it cannot only be the substrate of ubiquitination by Mdm2, of stabilization by ARF and of phosphorylation by DNA damage sensor kinases, but it is also target of oncogenes, overexpressed or activated genes -such is the case of Ras- in order to unleash the senescent state both in vivo and in vitro (Yaswen \& Campisi; Braig \& Schmitt, 2006)).

Senescence induced by the activation of tumor suppressor genes. Tumor suppressors pten and p53 are part of the group of genes most frequently inactivated or mutated in human cancer (Di Cristofano \& Pandolfi, 2000; Vogelstein et al. 2000). The relevance of these genes in the process of senescence induction is special due to the mutual dependence amongst them. This led Chen et al. to study in depth the involved mechanisms. They thus proved, in a prostate model for tumor progression in mice that the acute homozygotic loss of pten resulted in an increase in the levels and function of $\mathrm{p} 53$, which initiated the senescence program. While the sole loss of $p 53$ had no effect in the pten expression, the ablation of both genes led to tumor transformation in an unusually fast manner. These results show that senescence mediated by $\mathrm{p} 53$ acts as a barrier against cell proliferation after pten deletion both in vivo and in vitro, possibly because the complete loss of pten provokes p19arf accumulation and therefore induces cell senescence and p53 stabilization by inhibiting Mdm2 (Chen et al.).

On the other hand, the lack of a histone methyltransferase or of $p 53$ makes cells avoid senescence, while directly progressing into tumor transformation. Indeed, Braig et al. proved in a model for lymphomagenesis that Ras-induced senescence in transgenic mice with heterozygote lesions in suv39hl or in $p 53$ works as a tumor suppressor mechanism directly dependant on the action of suv39h1, a histone H3K9 methyltransferase. Thanks to its action, suv39h1 participates in the formation of SAHFs and therefore, in the silencing of growth-promoting genes -such as $E 2 F$ - in a process that involves the activation and support of $\mathrm{Rb}$ in a hipophosphorylated state. These results suggest that histone $\mathrm{H} 3 \mathrm{~K} 9$ me-associated senescence is a mechanism that in vivo effectively suppresses the Ras-induced lymphomagenesis (Braig et al.).

\section{Senescence induced by agents which cause DNA} damage. Several treatments against cancer produce damage in the DNA of malignant cells. In response to this aggression, cells that have their death or senescence activating mechanisms intact can irreversibly stop their growth, as has been shown in cancerous cell lines and in tumor biopsies. Thus, the HT1080 fibrosarcoma cell line expresses a senescent phenotype after treatment with antitumor agents doxorubicin, aphidicolin, cisplatin and, in smaller proportion, with cytarabine and etoposide or with exposition to ionizing radiation. The effect was less evident when the cells were treated with paclitaxel and vincristine. In addition to this, the presence of senescent cells has been identified in tumor biopsies performed before chemotherapy or radiotherapy, which indicates that tumor cells can undergo a sort of "spontaneous" senescence. Nonetheless, the number of senescent cells is considerably higher when there has previously been chemotherapy, as was proved by Te Poele $e t$ $a l$. They identified senescence markers in $41 \%$ of the frozen biopsies of tumor mammary tissue treated with cyclophosphamide, doxorubicin and 5-fluorouracil, in contrast to the reduced expression of such markers in normal mammary tissue. This counts as evidence that the senescent response was originated in the cancerous cells (Te Poele et al.). 
Because some tumor types are resistant to treatment with DNA damage inductors -a phenotype that is apparently related with a diminished capacity to activate the senescent state (Levenson et al., 1999)-, experiments have been carried out with differentiation inductor agents, such as sodium butyrate (Terao et al., 2001), derived from retinoic acid and cytokine TNF- $\beta$ (Katakura et al.), which can also induce senescence in tumor cells. For example, under treatment with retinoids, $p 21$ is responsible to lead the cell along the route of differentiation or along the route of senescence (Wainwright et al., 2001).

Although genes $p 53 k, p 21$ and $p 16$ participate in the regulation of both replicative senescence and accelerated senescence induced by genotoxic agents, it has been shown that in response to the chemical agent doxorubicin, events such as the absence, the mutation or the silencing of $p 53$ in cell lines Saos-2, Sw480, U251, Hela and Hep-2, do not interfere with the appearance of the senescent state. This fact suggests that the most important role of p53 is not precisely to lead the beginning of the senescent state, but rather to accelerate it (Roninson).

\section{Senescence as a promoting mechanism of tumorigenesis} Among patients with Li-Fraumeni syndrome, cells with mutated $p 53$ and $C h K 1$ suffer accelerated senescence, which frequently precedes cancer appearance (Shay et al., 1995, Iwakuma et al., 2005). On the other hand, the presence of cells with senescence marker expression in tissues with hyperplastic pathological or premalignant alterations might indicate that senescence is a step in the process of tumor transformation or, that cancer development is age-dependant (Campisi, 2003a,b). It turns out thus paradoxical that a tumor suppressor mechanism such as senescence might induce the development of cancer in late stages of life.

In order to explain the formation of pulmonary tumors in presence of $\mathrm{Kras}^{\mathrm{G} 12 \mathrm{DE}}$ and $\mathrm{Braf}^{\mathrm{V} 600 \mathrm{E}}$ mutations, Dankort $e t$ al. (2007) postulated that these genes were capable of inducing them through p 16 and p53 activation. According to their

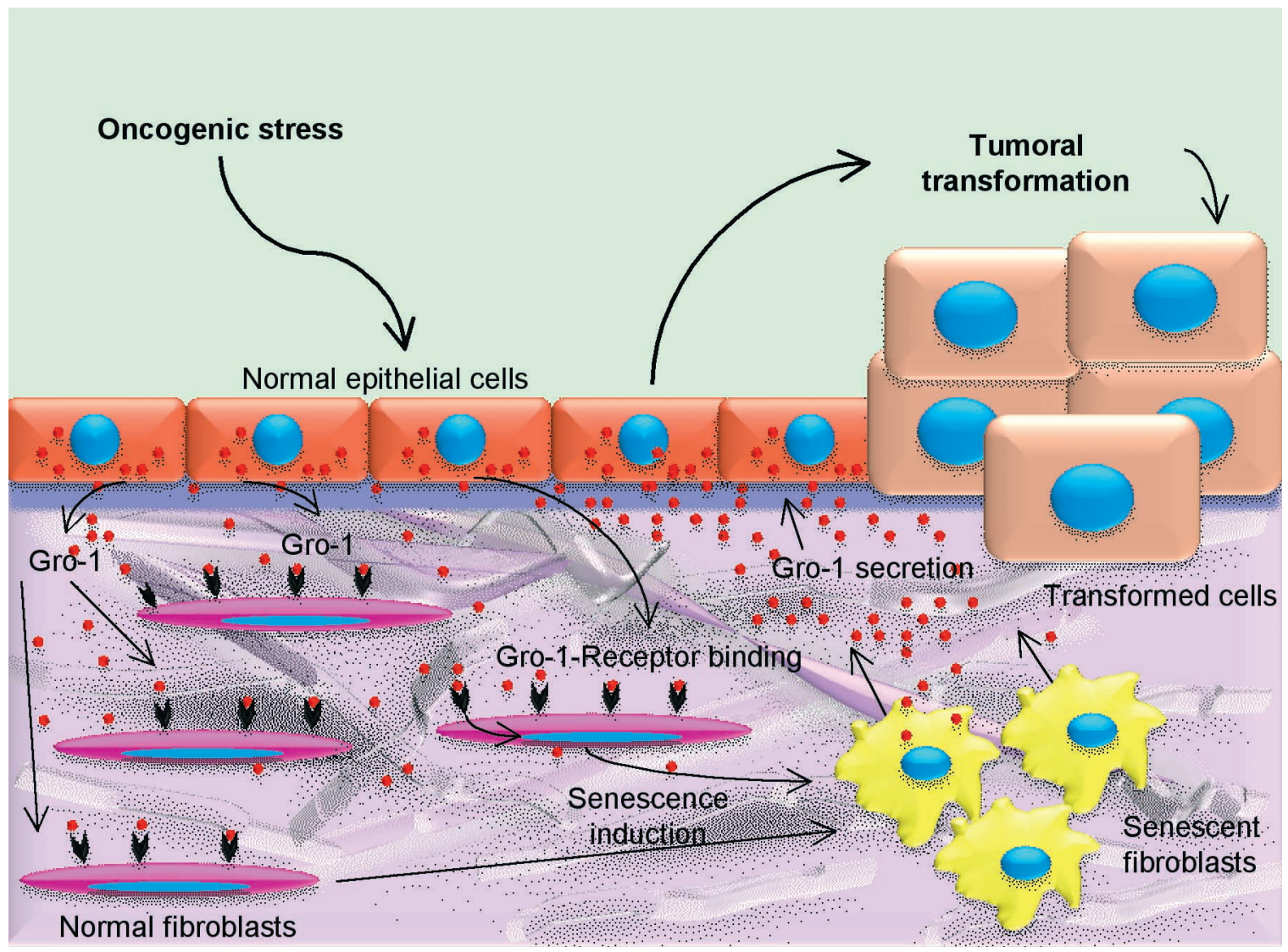

Fig. 3. The dual effect of Gro-1 on epithelial cells and fibroblasts. According to the model proposed by Yang et al (2006) epithelial cells initiate the secretion of chemokine Gro-1 when subject to oncogenic stress. The binding of Gro- 1 with specific receptors present in the stromal fibroblasts allows the nuclear activation of a p53-dependant signaling process which, at the same time, provokes the entry of the cell into a senescent state. The senescent fibroblasts begin to secrete Gro1 , which induces the tumor transformation of the epithelial cells. 
hypothesis, Erk, downstream substrate of Mek, Braf and Kras in the Mek signaling pathway, provokes a decrease in Ras activity and increases $p 16$ and $p 53$ expression, with the subsequent induction of senescence. Based on their findings in the lung alveolar stem cells from BASC and AT2pc lines, they identified a different malignancy potential in both genes. Thus, while Kras induces tumors in the BASC cell line that progress to carcinomas, the tumors induced in AT2pc cells suffer growth arrest in a similar way as in the Braf effect on this type of cells. The results obtained by Dankort et al. suggest that the inhibition of the Mek signaling pathway might be very useful as a therapeutic target against the development of carcinomas induced by Braf mutations due to Mek's capacity to promote regression and stabilization of tumors associated, not only to Braf, but also to p16 and p53 (Dankort et al.; Gayet et al.).

On the other hand, it has been proven that over expression of chemokine Gro-1 can provoke a malignant transformation of epithelial cells simultaneously with senescence induction in fibroblasts of the underlying stroma (Yang et al.; Lazar et al., 2000). There is no clarity, though, as to whether such senescent state appears before a possible tumor transformation of the same fibroblasts or, on the contrary, the senescent state protects them against it (Fig. 3).

Along these lines, it is valid to accept that senescence constitutes an important risk factor in the process of tumor transformation which, under normal conditions, should be stopped by control mechanisms that block the growth of the cells, activating thus their death (Wright \& Shay, 2001; Campisi, 2004).

Perspectives: Potential for the development of anticancerous drugs based on the tumoral suppressor effect of senescence. According to the pro and antitumorigenic effects of senescence previously described, the senescent cells present in a malignant lesion can constitute reservoirs of both suppressor and promoter factors of tumorigenesis. Suppressor factors in particular could be employed in order to reestablish the tumor suppressing function and to therefore inhibit cell proliferation in the cancerous lesion. Therefrom the importance of identifying the molecules that crucially regulate the cell processes altered in carcinogenesis. One example of this is the work done by the group of Liu et al., who studied the activity of SIRT1, a class III histone deacetylase that is not only capable of protein deacetylation but can also methylate DNA in the $\mathrm{CpG}$ sequences. SIRT1 activity is very low in normal cells, for its expression is repressed by antitumorigenic proteins $\mathrm{p} 53$, Chk2, HIC1 and DBC1. In contrast to this, as a result of the activation of the gene or to the exacerbation of its function, malignant cells exhibit an elevated SIRT1 activity which has been associated to events such as the beginning of a tumor, its progression or its resistance to certain medications (Liu et al.).

Studies conducted with SIRT1 inhibitors such as sirtinol, cambinol and tenovin have given promising results in therapy against cancer, for it has been demonstrated that they induce senescence in breast and lung tumoral cells, apoptosis in the Burkitt lymphoma and growth arrest in the melanoma. These facts indicate furthermore that the effect of such inhibitors is tissue-specific Liu et al.

Advances in the study of the biologic aspects of tumor senescence will provide valuable information for the development of new therapeutic strategies to stop tumor progression. It is likely to think that the new tools will include agents that interfere with the promoter factors of the disease or that induce senescence in malignant cells without stimulating tumor growth and with a long term effect.

CHUAIRE-NOACK, L.; SÁNCHEZ-CORREDOR, M. C. \& RAMÍREZ-CLAVIJO, S. Papel dual de la senescencia en la tumorigénesis. Int. J. Morphol., 28(1):37-50, 2010.

RESUMEN: La relación entre senescencia y transformación maligna ha sido objeto de particular atención, debido a una aparente dualidad de funciones, en la que la senescencia participaría tanto en la inducción como en la inhibición de la malignidad. El objetivo del trabajo fue revisar algunos de los hallazgos más recientes sobre el papel de la senescencia en la progresión maligna y analizarlos a la luz del concepto de la pleiotropía antagónica y de su posible utilización como blanco terapéutico contra el cáncer. Se considera a la senescencia como un mecanismo supresor tumoral, debido al efecto protector contra el cáncer que ejerce en organismos jóvenes, en caso de activación de oncogenes o de inactivación de genes supresores tumorales. Además de este efecto beneficioso, se le han adjudicado efectos deletéreos asociados con la edad pues, en apariencia, la senescencia no sólo recapitula el envejecimiento y por tanto la pérdida de función y capacidad de regeneración tisular, sino también puede inducir cambios preneoplásicos en las células del estroma adyacente, provocar enfermedades degenerativas o inducir la secreción de factores promotores del crecimiento de células tumorales. La aparición de defectos en el programa de senescencia puede contribuir a la transformación tumoral, lo que la ha convertido en un atractivo blanco terapéutico contra el cáncer. El avance en el estudio de los aspectos biológicos de la senescencia proporcionará valiosa información para el desarrollo de nuevas estrategias terapéuticas que detengan la progresión tumoral. 


\section{REFERENCES}

Bartkova, J.; Rezaie, N.; Liontos, M.; Karakaidos, P.; Kletsas, D.; Issaeva, N.; Vassiliou, L.V.; Kolettas, E.; Niforou, K.; Zoumpourlis, V. C.; Takaoka, M.; Nakagawa, H.; Tort, F.; Fugger, K.; Johansson, F.; Sehested, M.; Andersen, C. L.; Dyrskjot, L.; Ørntoft, T.; Lukas, J.; Kittas, C.; Helleday, T.; Halazonetis, T. D.; Bartek, J. \& Gorgoulis, V. G. Oncogene-induced senescence is part of the tumorigenesis barrier imposed by DNA damage checkpoints. Nature, 444:633-7, 2006.

Bavik, C.; Coleman, I.; Dean, J. P.; Knudsen, B.; Plymate, S. $\&$ Nelson, P. S. The gene expression program of prostate fibroblast senescence modulates neoplastic epithelial cell proliferation through paracrine mechanisms. Cancer Res., 66:794-802, 2006.

Beausejour, C. M. \& Campisi, J. Balancing regeneration and cancer. Nature, 443:4004-5, 2006.

Ben-Porath, I. \& Weinberg, R. A. The signals and pathways activating cellular senescence. Int. J. Biochem. Cell Biology, 37:961-76, 2005.

Braig, M.; Lee, S.; Loddenkemper, C.; Rudolph, C.; Peters, A.; Schlegelberger, B.; Stein, H.; Doerken, B.; Jenuwein, T. \& Schmitt, C. A. Oncogene-induced senescence as an initial barrier in lymphoma development. Nature, 436:660$5,2005$.

Braig, M. \& Schmitt, C. A. Oncogene-induced senescence: putting the brakes on tumor development. Cancer Res., 66:2881-4, 2006.

Burton, D. G. A. Cellular senescence, ageing and disease. Age 31:1-9, 2009.

Campisi, J. \& D'Adda di Fagagna, F. Cellular senescence: When bad things happen to good cells. Mol. Cell. Biol., 8:729-40, 2007.

Campisi, J. Aging, tumor suppression and cancer: High-wire act! Mech Ageing Dev. 2004. En: http://www.elsevier.com/ locate/mechagedev (Ultimo acceso: marzo 9 de 2009).

Campisi, J. Cancer and ageing: rival demons? Nat. Rev. Cancer, 3:339-49, 2003a.

Campisi, J. Cellular senescence and apoptosis: How cellular responses might influence ageing phenotypes. Exp. Geront, 38:5-11, 2003 b.
Campisi, J. Cellular senescence as a tumour-suppressor mechanism. Trends Cell Biol., 11:S2-S31, 2001.

Carnero, A. Cellular senescence as a target in cancer control. Curr. Canc. Ther. Rev., 3:3-15, 2007.

Chen, Z.; Trotman, L. C.; Shaffer, D.; Lin, H. K.; Dotan, Z. A.; Niki, M.; Koutcher, J. A.; Scher, H. I.; Ludwig, T.; Gerald, W.; Cordon-Card, C. \& Pandolfi, P. P. Crucial role of p53-dependent cellular senescence in suppression of PTEN deficient tumorigenesis. Nature, 436:725-30, 2005.

Collado, M.; Gil, J.; Efeyan, A.; Guerra, C.; Schuhmacher, A. J.; Barradas, M.; Benguria, A.; Zaballos, A.; Flores, J. M.; Barbacid, M.; Beach, D. \& Serrano, M. Tumour biology: senescence in premalignant tumours. Nature, 436:642, 2005.

Collado, M. \& Serrano, M. The power and the promise of oncogene induced senescence markers. Nature Rev. Cancer, 6:472-6, 2006.

Coppé, J. P.; Kauser, K.; Campisi, J. \& Beausejour, C. M. Secretion of vascular endothelial growth factor by primary human fibroblasts at senescence. J. Biol. Chem. 281:29568-74. 2006.

Coppé, J. P.; Patil, C. K.; Rodier, F.; Sun, Y.; Muñoz, D. P.; Goldstein, J.; Nelson, P. S.; Desprez, P. I. \& Campisi, J. Senescence-associated secretory phenotypes reveal cell-nonautonomous functions of oncogenic RAS and the p53 tumor suppressor. Plos. Biology, 6:2853-68, 2008.

Cosme-Blanco, W.; Shen, M. F.; Lazar, A. J.; Pathak, S.; Lozano, G.; Multani, A. S. \& Chang, S. Telomere dysfunction suppresses spontaneous tumorigénesis in vivo by initiating p53-dependent cellular senescence. EMBO, 8:497-503, 2007.

Courtois-Cox, L.; Genther-Williams, S. M.; Reczek, E. E.; Johnson, B.W.; McGillicuddy, L.T.; Johannessen, L. M.; Hollstein, P. E.; MacCollin, M. \& Cichowski, K. A negative feedback signaling network underlies oncogene-induced senescence. Cancer Cell, 10:459-72, 2006.

Dankort, D., Filenova, E., Collado, M., Serrano, M., Jones, K. \& McMahon, M. A new mouse model to explore the initiation, progression, and therapy of BRAFV600E-induced lung tumors. Genes Dev., 21: 361-366, 2007. 
Di Cristofano, A. \& Pandolfi, P. P. The multiple roles of PTEN in tumour suppression. Cell, 100:387-90, 2000.

Dimri, G.P., Lee, X., Basile, G., Acosta, M., Scott, G., Roskelley, C., Medrano, E.E., Linskens, M., Rubelj, I., Pereira-Smith, O., Peacocke, M., \& Campisi, J. A biomarker that identifies senescent human cells in culture and in aging skin in vivo. Proc. Natl. Acad. Sci, USA. 92:9363-7, 1995.

Duan, J.; Duan, J.; Zhang, Z. \& Tong, T. Irreversible cellular senescence induced by prolonged exposure to $\mathrm{H} 2 \mathrm{O} 2$ involves DNA-damage-and-repair genes and telomere shortening. Int. J. Biochem. Cell Biol., 37:1407-20, 2005.

Feldser, D.M. \& Greider, C.W. Short telomeres limit tumor progression in vivo by inducing senescence. Cancer Cell 11:461-9, 2007.

Fuxe, J.; Akusjärvi, G.; Goike, H. M.; Roos, G.; Collins, V. P. \& Pettersson, R. F. Adenovirus-mediated overexpression of p15INK4B inhibits human glioma cell growth, induces replicative senescence, and inhibits telomerase activity similarly to p16INK4A. Cell Growth Differ., 11:373-384, 2000.

Gayet, J.; Zhou, X. P.; Duval, A.; Rolland, S.; Hoang, J. M.; Cottu, P. \& Hamelin, R. Extensive characterization of genetic alterations in a series of human colorectal cancer cell lines. Oncogene, 20:5025-32, 2001.

Gerwitz, D. A.; Holt, S.E. \& Elmore, L. W. Accelerated senescence: An emerging role in tumor cell response o chemotherapy and radiation. Biochem. Pharmacol., 76:947-957, 2008.

Gil, J. \& Peters, G. Regulation of the INK4b-ARF-INK4a tumour suppressor locus: all for one or one for all. Nat. Rev. Mol. Cell. Biol., 7:667-77, 2006.

Hayflick, L. \& Moorhead, P. S. The serial cultivation of human diploid cell strains. Exp. Cell. Res., 25:585-621, 1961.

Itahana, K.; Zou, Y.; Itahana, Y.; Martinez, J. L.; Beausejour C.; Jacobs, J. J.; Van Lohuizen, M.; Band, V.; Campisi, J. \& Dimri, G. P. Control of the replicative life span of human fibroblasts by $\mathrm{p} 16$ and the polycomb protein Bmi1. Mol. Cell Biol., 23:389-401, 2003.

Iwakuma, T.; Lozano, G. \& Flores, E. R. Li Fraumeni syndrome: a p53 family affair. Cell Cycle, 4:865-7, 2005.
Janzen, V.; Forkert, R.; Fleming, H. E.; Saito, Y.; Waring, M. T.; Dombkowski, D. M.; Cheng, T.; DePinho, R. A.; Sharpless, N. E. \& Scadden, D.T. Stem-cell ageing modified by the cyclin-dependent kinase inhibitor p16INK4a. Nature, 443:421-6, 2006.

Jeyapalan, J. C.; Ferreira, M.; Sedivy, J. M. \& Herbig, U. Accumulation of senescent cells in mitotic tissue of aging primates. Mech. Ageing Dev., 128:36-4, 2007.

Jung, M. S.; Yun, J.; Chae, H. D.; Kim, J. M.; Kim, S. C.; Choi, T. S. \& Shin, D.Y. p53 and its homologues, p63 and $\mathrm{p} 73$, induce a replicative senescence through inactivation of NF-Y transcription factor. Oncogene, 20:5818-25, 2001.

Katakura, Y.; Nakata, E.; Miura, T. \& Shirahata, S. Transforming growth factor beta triggers two independent-senescence programs in cancer cells. Biochem. Biophys Res. Commun, 255:110-5, 1999.

Katakura, Y. Molecular basis for the cellular senescence program and its application to anticancer therapy. Biosci. Biotechnol. Biochem., 70:1076-81, 2006.

Kilbey, A.; Terry, A.; Cameron, E. R. \& Neil, J. C. Oncogene induced senescence Cell. Cyclem, 7:2333-40, 2008.

Kirkwood, T. B. \& Austad, S. N. Why do we age? Nature, 408:233-8, 2000.

Kletsas, D.; Pratsinis, H.; Mariatos, G.; Zacharatos, P. \& Gorgoulis, V.G. The proinflammatory phenotype of senescent cells: the p53-mediated ICAM-1 expression. Ann. N. Y. Acad. Sci., 1019:330-2, 2004.

Krishnamurthy, J.; Ramsey, M. R.; Ligon, K. L.; Torrice, C.; Koh, A., Bonner-Weir, S. \& Sharpless, N.E. p16INK4a induces an age-dependent decline in islet regenerative potential. Nature, 443:453-7, 2006.

Krishnamurthy, J.; Torrice, C.; Ramsey, M. R.; Kovalev, G. I.; Al-Regaiey, K.; Su, L. \& Sharpless, N.E. Ink4a/Arf expression is a biomarker of aging. J. Clin. Invest., 114: 1299-307, 2004.

Krtolica, A. \& Campisi, J. Cancer and aging: a model for the cancer promoting effects of the aging stroma. Int. J. Biochem. Cell. Biol., 34:1401-14, 2002.

Lazar, M. E.; Hegyesi, H.; Toth, S. \& Falus, A. Autocrine and paracrine regulation by cytokines and growth factors in melanoma. Cytokine, 12:547-54, 2000. 
Lee, B. Y.; Han, J. A.; Im, J. S.; Morrone, A.; Johung, K.; Goodwin, E. C.; Kleijer, W. J.; DiMaio, D. \& Hwang, E. S. Senescence-associated B-galactosidase is lysosomal B-galactosidase. Aging Cell, 5:187-95, 2006.

Levenson, V. V.; Lausch, E.; Kirschling, D. J.; Broude, E. V.; Davidovich, I. A.; Libants, S.; Fedosova, V. \& Roninson, I. B. A combination of genetic suppressor elements produces resistance to drugs inhibiting DNA replication. Somat. Cell. Mol. Genet., 25:9-26, 1999.

Libby, P. Inflammation and cardiovascular disease mechanisms Am. J. Clin. Nutr., 83 (suppl):456S-460S, 2006.

Lin, A. W.; Barradas, M.; Stone, J. C.; van Aelst, L.; Serrano, M. \& Lowe, S.W. Premature senescence involving p53and p16 is activated in response to constitutive MEK/ MAPK mitogenic signaling. Genes Dev., 12:3008-19, 1998.

Liu, T.; Liu, P. Y. \& Marshall, G. M. The Critical Role of the Class III Histone Deacetylase SIRT1 in Cancer. Cancer Res., 69:1702-05, 2009.

Lowe, S.W.; Cepero, E. \& Evan, G. Intrinsic tumor suppression. Nature, 432:307-15, 2004.

Lu, T. \& Finkel, T. Free radicals and senescence. Exp. Cell. Res., 314:1918-22, 2008.

Mallette, F. A.; Gaumont-Leclerc, M. F. \& Ferbeyre, G. The DNA damage signaling pathway is a critical mediator of oncogene-induced senescence. Genes Dev., 21:23-48. 2007.

Mason, D. X.; Jackson, T. J. \& Lin, A. W. Molecular signature of oncogene ras-induced senescence. Oncogene, 23:9238-46, 2004.

Michaloglou, C.; Vredeveld, L. C.; Soengas, M. S.; Denoyelle, C.; Kuilman, T.; van der Horst, C. M.; Majoor, D. M.; Shay, J. W.; Mooi, W. J. \& Peeper, D.S. BRAFE600-associated senescence-like cell cycle arrest of human naevi. Nature, 436:720-4, 2005.

Molofsky, A.V.; Slutsky, S. G.; Joseph, N. M., He, S.; Pardal, R.; Krishnamurthy, J.;Sharpless, N. E. \& Morrison, S.J. Increasing p16INK4a expression decreases forebrain progenitors and neurogenesis during ageing. Nature, 443:448-52, 2006.

Narita, M.; Nunez, S.; Heard, E.; Narita, M.; Lin, A. W.,
Hearn, S. A.; Spector, D. L.; Hannon, G. J. \& Lowe, S.W. Rb-mediated heterochromatin formation and silencing of E2F target genes during cellular senescence. Cell, 113:703-16, 2003.

Narita, M. Cellular senescence and chromatin organisation. Br. J. Cancer, 96:686-691, 2007.

Okada, H. \& Mak, T.W. Pathways of apoptotic and nonapoptotic death in tumour cells. Nat. Rev. Cancer, 4:592-603, 2004.

Pascal, T.; Debacq-Chainiaux, F.; Chretien, A.; Bastin, C.; Dabee, A. F.; Bertholet, V.; Remacle, J. \& Toussaint, O. Comparison of replicative senescence and stress-induced premature senescence combining differential display and low-density DNA arrays. FEBS Lett., 579:3651-9, 2005.

Passegue, E. \& Wagner, E.F. JunB suppresses cell proliferation by transcriptional activation of p16(INK4a) expression. EMBO J., 19:2969-79, 2000.

Pazolli, E. \& Stewart, S.A. Senescence: the good the bad and the dysfunctional. Curr. Opin. Genet. Dev., 18:427, 2008.

Qian, Y.; Zhang, J.; Yan, B. \& Chen, X. Dec1, a bHLH transcription factor and a novel target gene of the p53 family mediates p53-dependent premature senescence. J. Biol. Chem., 283:2896-905, 2008.

Ramsey, M. R. \& Sharpless, N. E. ROS a tumour suppressor? Nat. Cell. Biol., 8:1213-5, 2006.

Roberson, R. S.; Kussick, S. J.; Vallieres, E.; Chen, S. Y. \& $\mathrm{Wu}, \mathrm{D} . \mathrm{Y}$. Escape from therapy-induced accelerated cellular senescence in p53 null lung cancer cells and in human lung cancers. Cancer Res., 65:2795-803, 2005.

Roninson, I.B. Tumor cell senescence in cancer treatment. Cancer Res., 63:2705-15, 2003.

Salvioli, S.; Capri, M.; Valensin, S.; Tieri, P.; Monti, D.; Ottaviani, E. \& Franceschi, C. Inflamm-aging, cytokines and aging: state of the art, new hypotheses on the role of mitochondria and new perspectives from systems biology. Curr. Pharm. Des., 12:3161-71, 2006.

Schmitt, C. A.; Fridman, J. S.; Yang, M.; Lee, S.; Baranov, E.; Hoffman, R. M. \& Lowe, S. W. A senescence program controlled by p53 and p16ink4a contributes to the outcome of cancer therapy. Cell, 109:335-46, 2002. 
Schmitt, C.A. Senescence, apoptosis and therapy-cutting the lifelines of cancer. Nat. Rev. Cancer, 3:286-95, 2003.

Schwarze, S. R.; Fu, V. X.; Desotelle, J. A.; Kenowsky, M. L. \& Jarrard, D. F. The identification of senescencespecific genes during the induction of senescence in prostate cancer cells. Neoplasia, 7:816-23, 2005.

Serrano, M.; Lin, A.W.; McCurrach, M. E.; Beach, D. \& Lowe, S. W. Oncogenic ras provokes premature cell senescence associated with accumulation of p53 and p16ink4a. Cell, 88:593-602, 1997.

Sharpless, N. E. Ink4a/Arf links senescence and aging. Exp. Gerontol., 39:1751-9, 2004.

Shay, J. W.; Tomlinson, G.; Platyszech, M. A. \& Gollahon, L. S. Spontaneous in vitro immortalization of breast epithelial cells from a patient with Li Fraumeni syndrome. Mol. Cell. Biol., 15:425-32, 1995.

Song, Z.; Wang, Y.; Xie, L.; Zang, X. \& Yin, H. Expression of senescence-related genes in human corneal endothelial cells. Mol. Vis., 14:161-70, 2008.

Sprenger, C. C.; Vail, M. E.; Evans, K.; Simurdak, J. \& Plymate, S. R. Over-expression of insulin-like growth factor binding protein-related protein-1(IGFBP-rP1/ mac25) in the M12 prostate cancer cell line alters tumor growth by a delay in $\mathrm{G} 1$ and cyclin A associated apoptosis. Oncogene, 21:140-7, 2002.

Sun, P.; Yoshizuka, N.; New, L.; Moser, B. A.; Li, Y.; Liao, R.; Xie, C.; Chen, J.; Deng, Q.; Yamout, M.; Dong, M. Q.; Frangou, C. G.; Yates, J. R. 3rd.; Wright, P. E. \& Han, J. PRAK is essential for ras-induced senescence and tumor suppression. Cell, 128:295-308, 2007.

Takai, H., Smogorzewska, A. \& de Lange, T. DNA Damage Foci at Dysfunctional Telomeres. Curr. Biol., 13:154956, 2003.

Te Poele, R. H.; Okorokov, A. L.; Jardine, L.; Cummings, J. \& Joel, S. P. DNA damage is able to induce senescence in tumor cells in vitro and in vivo. Cancer Res., 62:1876-83, 2002.

Terao, Y.; Nishida, J.; Horiuchi, S.; Rong, F.; Ueoka, Y.; Matsuda, T.; Kato, H.; Furugen, Y.; Yoshida, K.; Kato, K. \& Wake, N. Sodium butyrate induces growth arrest and senescence-like phenotypes in gynecologic cancer cells. Int. J. Cancer, 94:257-67, 2001.
Tsugu, A.; Sakai, K.; Dirks, P. B.; Jung, S.; Weksberg, R.; Fei, Y. L.; Mondal, S.; Ivanchuk, S.; Ackerley, C.; Hamel, P. A. \& Rutka, J.T. Expression of p57(KIP2) potently blocks the growth of human astrocytomas and induces cell senescence. Am. J. Pathol., 157:919-32, 2000.

Vogelstein, B.; Lane, D. \& Levine, A. J. Surfing the p53 network. Nature, 408:307-10, 2000.

Wainwright, L. J.; Lasorella, A. \& Iavarone, A. Distinct mechanisms of cell cycle arrest control the decision between differentiation and senescence in human neuroblastoma cells. Proc. Natl. Acad. Sci. USA,, 98:9396-400. 2001.

West, M. D.; Pereira-Smith, O. M. \& Smith, J. R. Replicative senescence of human skin fibroblasts correlates with a loss of regulation and overexpression of collagenase activity. Exp. Cell. Res., 184:138-47, 1989.

Wright, W. E. \& Shay, J. W. Cellular senescence as a tumor-protection mechanism: the essential role of counting. Curr. Opin. Genet. Dev., 11:98-103, 2001.

Wu, J.; Xue, L.; Weng, M.; Sun, Y.; Zhang, Z.; Wang, W. \& Tong, T. Sp1 is essential for $\mathrm{p} 16$ expression in human diploid fibroblasts during senescence. PLOS. ONE 2:e164. 2007.

Yang, G.; Rosen, D. G.; Zhang, Z.; Bast, R. C. Jr.; Mills, G. B.; Colacino, J. A.; Mercado, I. \& Liu, J. The chemokine growth-regulated oncogene 1 (Gro 1) links Ras signaling to the senescence of stromal fibroblasts and ovarian tumorigenesis. PNAS, 103:16472-7, 2006.

Yaswen, P. \& Campisi, J. Oncogen-induced senescence pathways weave an intrincate tapestry. Cell ,128:233234, 2007.

Zhang, M.; Poustovoitov, X.; Ye, H.; Santos, W.; Chen, S.; Daganzo, J.; Erzberger, J. P.; Serebriiskii, I. G.; Canutescu, A. A.; Dunbrack, R. L.; Pehrson, J. R.; Berger, J. M.; Kaufman, P. D. \& Adams, P. D. Formation of MacroH2A-Containing SenescenceAssociated Heterochromatin Foci and Senescence Driven by ASF1a and HIRA. Dev. Cell, 8:19-30, 2005.

Zhang, Y.; Xiong, Y. \& Yarbrough, W.G. ARF promotes MDM2 degradation and stabilizes p53: ARF-INK4a locus deletion impairs both the $\mathrm{Rb}$ and $\mathrm{p} 53$ tumor suppression pathways. Cell, 92:725-34, 1998. 
CHUAIRE-NOACK, L.; SÁNCHEZ-CORREDOR, M. C. \& RAMíREZ-CLAVIJO, S. The dual role of senescence in tumorigenesis. Int. J. Morphol., 28(1):37-50, 2010.

Zheng, W.; Wang, H.; Xue, L.; Zhang, Z. \& Tong, T. Regulation of Cellular Senescence and p16INK4a Expression by Id1 and E47 Proteins in Human Diploid Fibroblast. J. Biol. Chem., 279:31524-32, 2004.
Correspondence to: Lilian Chuaire-Noack Carrera 24 \# 63C-69 Quinta de Mutis Bogotá DC 11001 COLOMBIA

E-mail: Ichuaire@urosario.edu.co

Received: 18-06-2009

Accepted: 28-07-2009 